\title{
Subsidized Regional Airlines as a Sustainable Development Mechanism for Remote Locations Heavily Dependent on Air Transportation
}

\author{
Celso José Leão e Silva ${ }^{1}$, Maurício Oliveira de Andrade $^{1}$, Viviane Adriano Falcão ${ }^{1}$ \& Carlos Fabrício \\ Assunção da Silva ${ }^{1}$ \\ ${ }^{1}$ Federal University of Pernambuco, Brazil \\ Correspondence: Celso José Leão e Silva, Federal University of Pernambuco, Brazil. E-mail: \\ celsojleao@gmail.com
}

Received: June 27, 2021

Accepted: July 28, $2021 \quad$ Online Published: July 29, 2021

doi:10.5539/jsd.v14n4p108

URL: https://doi.org/10.5539/jsd.v14n4p108

\begin{abstract}
The understanding that air transport induces the economic development of a region has motivated studies on regional air transport and the necessary subsidies for its implementation. Several countries have implemented specific subsidy plans with a focus on integrating their territories through a network of air routes, depending on the funding methods and the results of the investments that were made. However, few studies summarize the geographical conditions of the locations served that justify their dependence on air transport as the only viable means of accessibility. This article seeks to identify the geographical characteristics of these locations to illustrate the conditions that justify the need for subsidies for the operationalization of air transport as a mechanism to promote the minimum sustainability conditions for such locations. We collected socioeconomic data of a set of 1365 subsidized routes of 28 countries from the Americas, Asia, Europe, and Oceania and tracing a profile of localities, classified in nine different clusters. The results indicated that isolated locations in islands, in the polar regions and areas of impenetrable forests have an almost exclusive dependence on air transport as a means of access and that justify the maintenance of subsidies to air routes as a fundamental requirement for the accessibility of the population to services of a social and humanitarian nature.
\end{abstract}

Keywords: subsidized air routes, regional aviation, accessibility, air lifelines

\section{Introduction}

Air transportation represents a means of transport generally associated with travel over long distances, and presents itself in some parts of the world as a mode of travel used to reduce travel time or to overcome physical barriers that make surface means unattractive or even unfeasible.

Government policies for subsidizing air transport were sequenced throughout the twentieth century under different characteristics and with a focus on specific agents. They were represented by airport infrastructure managers, through the financing of renovations, construction and expansion of airports and airlines, and through operations of state-owned airlines (Garcia, 1983; Fengjun, Fahui and Yu, 2004; Masayochi and Trevor, 2012; Ryerson and Woodburn, 2014; Turolla, Lima and Ohira, 2011).

This phenomenon has spread around the world since the 1978 Airline Deregulation Act in the United States, stimulating the birth of new low-cost companies, which resulted in the evident incorporation of new passengers into air transport (Wittman, Allroggen and Robert, 2016).

However, countries that are among the largest global air transport markets, like the United States, China, the United Kingdom and Japan, until now have subsidy policies to ensure connectivity from remote locations in their own territories to airports served by regular airlines networks. Grubesic and Wei (2012) provide an analysis of the efficiency of the American program Essential Air Service (EAS). Bråthen and Halpbern (2012) evaluate the strategies adopted by the United States and European countries through the Public Service Obligations (PSO) program. Bråthen and Eriksen (2016) discuss a model to determine the social efficiency of subsidized routes in Norway, one of the most benefited by said program. Other regions that are characterized by their geographical position close to the poles of the planet, such as Canada, with arctic 
communities that are of difficult or non-existent route on land; and Chile, with isolated communities in the Province of Magalhães, is also present in airline subsidy programs. The service to these remote locations is based on various criteria and forms, but always with the same purpose of connecting them to the respective air transport networks.

Thus, there is a set of information available about regional transport subsidy policies in several countries, which serve locations not included in the airline network and which can have economic development when served by air transport. However, many of these locations are notisolated or do not depend exclusively on air transport, since they are accessible by land or water. On the other hand, a set of locations that, in addition to not being part of the airline network and that would also develop if served by air transport, correspond to extremely isolated communities that depend exclusively on air transport for their most basic needs, such as lifelines for primarily humanitarian and social assistance. However, these locations do not typically represent the focus of air transport subsidy studies.

\subsection{Research Objectives}

(i) To explore how diverse public policy programs of incentives and subsidies are to the operation of air transport in different countries of the world with several levels of dependence on air transport to function as sufficiently sustainable locations from the perspective of various basic services, such as supply, health and education.

(ii) To map the lines and locations served in order to infer about the types of situations that led to the adoption of subsidy policies, especially in isolated locations.

(iii) To understand the relative importance of different programs in reaching isolated populations, for humanitarian, national security and/or economic reasons;

(iv) To identify criteria for classifying subsidized air routes as lifelines.

\subsection{Literature Review}

The International Air Transport Association (IATA, 2018) pointed out that 22,000 city pairs are connected by direct flights worldwide, with an increase of 1,300 cities compared to 2017 and almost twice as many cities connected back in 1998, a time when 10,250 city pairs had routine direct flights globally.

Even in countries with high rates of per capita use of air transport, there is a concern about the connectivity of regions disconnected in their territories. Thus, in view of the degree of isolation of many regions and communities, they seek a way to connect them by air to cities better equipped with health, education and supply services, especially when these represent islands, regions that are not easily accessible by land due to the precarious conditions of the access roads, over long distances, or due to weather conditions that make it impossible to travel by surface. According to Bråthen and Halpern (2012), the services provided by air transport are a key factor in the transport system in remote regions, as they allow human and natural resources to be more efficiently used.

With a focus on air transport, discussions have gathered around the topics of the provision of regional transport in several aspects, as they involve the selection of modes of transport, travel times and areas of influence from one location to another, which may vary as a result of socioeconomic, infrastructural, and political aspects. However, there is no explicit rule that broadly defines internal relations and, consequently, the needs for displacement. Much like the concept of "region", it could not be dissimilar that the definition of regional aviation is subject to several factors.

For Humphreys and Francis (2002), the role that regional airports play depends frequently on the decisions of airlines in relation to the choice of airports to operate in and their responses to capacity restrictions and regulatory and planning laws..

Several authors focus on the analysis of incentives for regional air transport through public subsidy policies: Wittmann, Allroggen and Robert (2016) write that 11 European countries resorted to subsidy programs in 2010 , noting that in the analyzed group $90 \%$ of the routes analyzed represented only $2.5 \%$ of all commercial movements registered in these countries. Skipin and Gushchina (2018) and Краев, Строев and Тихонов (2018) point out that, in the Russian Federation, the subsidy guarantees the offer of affordable fares to the population for the development of regional routes, determined by the conditions of limited public funds and low business activity in infrastructure projects, with a development strategy that begins with an improvement in the network of regional airports, followed by an innovative second phase of meeting social transport demands for the country's connectivity. Gassanova and Madikenova (2017) analyzed statistical data on the 
number of airports, airlines and passengers transported from 2011 to 2015 in Kazakhstan and concluded the development of domestic flights was conditional on the possibility of subsidizing demand consolidation. Dong and Ryerson (2019) and Chen et al (2016) indicate that in China the priority has been to adapt the capacity of the country's airports to the continuous growth of passenger movements, with the modernization of existing infrastructures, acting both in financing the construction of new airports as well as on offering subsidy to companies. Merket (2017) points out that the Remote Air Service Subsidy (RASS) is essential not only for economical sustainability, but also for the survival of local communities in Australia, where in many jurisdictions these services are known as lifeline services. Keeling (2008); Bråthen and Halpern (2012); Grubesic and Wei (2012), Gillen and Hazledine (2015), Fu and Kim (2016) analyzed the subsidy policy according to EAS in the United States air transport market, the largest in the world. Merkert and Williams (2013) believe that routes subsidized as PSO in Europe are often necessary so that communities do not remain isolated due to geographical conditions or because they are located in regions of low economic development.

For Fageda et al (2018), "remote regions", "isolated communities" and "non-commercial routes or destinations" represent reasons for the establishment of policies aimed at providing connectivity to places such as outermost territories, islands or regions with political demands. When analyzing the international experience, the authors realized that the policies adopted by the countries are concentrated in the following categories: i) route-based policies; ii) passenger-based policies; iii) airline-based policies; and iv) airport-based policies. They also noted that in some countries there may be a combination of these policies related to air connectivity in remote regions.

Although the concepts of "remote" and "isolated" can refer to locations in similar conditions of remoteness, the terms tend to be differentiated from a more social and health perspective, characterizing as "remote" locations that are distant from service centers but that permit access by land, while "isolated" are those communities without this access mode, during part or all period of the year (Young and Grobelna, 2018).

Therefore, there is a gap in the air transport literature of how and under what conditions subsidized regional routes can be analyzed in extremely isolated and economically unviable locations. Legislators have always seen air transport as the primary alternative to guarantee access to remote regions (or with a limited level of infrastructure) and as a means of favoring economic and social development. In disadvantaged geographical areas or with a low level of infrastructure, the air transport services offered are often considered as lifeline services (Laurino et al, 2017), as they serve extremely isolated communities that depend almost exclusively on air transport to connect their inhabitants with other centers, in search of basic services and essential products.

In an analysis of more than 100 articles published on civil aviation subsidies, Wu et al. (2020) focused their research on publications in the English language and in the European Union countries and the United States, historical implementers of air transport subsidy policies. Finally, they suggest researching publications in other languages and in other countries like Brazil, Chile, China, and India, pointing out a guideline for conducting new studies.

Retrieving articles and information from 28 countries around the world, also published on government websites in local languages, such as Portuguese, Spanish, Russian, Indonesian, and Chinese, this article seeks to identify the geographical characteristics of localities in countries on different continents, sizes and populations that become extremely dependent on subsidized air routes as lifeline connections, in humanitarian and social care.

\section{Methodology}

The first step in identifying the largest possible number of routes subsidized by different countries in the world was to search several databases from an initial list that included the largest countries in territorial extension, the largest domestic passenger markets and other countries with territory under special climate and forest coverage conditions. In this list, the research was limited to domestic routes only. No data were found for Argentina and Mexico, where government initiatives are more focused on operationalizing national and international routes (Wallingre, 2010; Argentina, 2019; Cruz-Rodriguez and Rodríguez-Flores, 2019). There were also no records of subsidy policies for regional routes in African countries, where government initiatives are more concentrated in the development of air transport among countries on the continent (SAATM, 2017). Initially, a survey was carried out to identify subsidies programs for regional routes through several sources:

(i) Scientific articles in periodicals and specialized magazines published between 1970 and 2020, through research with the keywords "regional aviation", "subsidized routes", "remote and isolated locations" and/or "regional routes";

(ii) Official websites of the governments of each country, bulletins and official publications, statistical reports from national, regional and autonomous communities; 
(iii) Local press with information on the implementation of air route subsidy programs to remote and isolated locations.

From this, 1,365 subsidized air routes were identified in 28 countries, including nine of the ten largest countries in the world in territorial extension and the eight largest domestic air transport markets worldwide.

The second step was carried out to find information regarding population and GDP per capita data of the cities of origin, distance traveled on the route and their condition of overland travel. Table 1 summarizes the researched data and its sources.

Table 1. Variables - definitions and query sources

\begin{tabular}{|c|c|c|}
\hline Variable & Information considered & Sources \\
\hline $\begin{array}{l}\text { Geographic } \\
\text { coordinate system }\end{array}$ & $\begin{array}{l}\text { Latitude and longitude of airports and } \\
\text { airfields in the locations served }\end{array}$ & $\begin{array}{l}\text { www.gcmap.com and location in } \\
\text { satellite image with search for } \\
\text { coordinates at google.com/maps }\end{array}$ \\
\hline Population & $\begin{array}{l}\text { Number of inhabitants of the area served, } \\
\text { considering the most recent data among } \\
\text { censuses carried out in } 2010 \text { or existing } \\
\text { projections for } 2016 \text { to } 2018 \text {. }\end{array}$ & $\begin{array}{l}\text { Official statistics data sites for } \\
\text { governments, the European Union, and } \\
\text { administrative reports for small } \\
\text { communities }\end{array}$ \\
\hline GDP per capita & $\begin{array}{l}\text { Gross domestic product per inhabitant in } \\
2018 \text { by region, state, or province in which } \\
\text { the region served is located }\end{array}$ & $\begin{array}{l}\text { Official statistics data sites for } \\
\text { governments, the European Union and } \\
\text { administrative reports for small } \\
\text { communities }\end{array}$ \\
\hline Route distance & Aerial distance in kilometers & $\begin{array}{l}\text { www.skyvector.com and calculation of } \\
\text { distance between coordinates or } \\
\text { measurement at google.com } / \text { maps. }\end{array}$ \\
\hline $\begin{array}{l}\text { Accessibility } \\
\text { land }\end{array}$ & $\begin{array}{l}\text { Existence of surface route by road or } \\
\text { highway }\end{array}$ & $\begin{array}{l}\text { Route simulation between route origin } \\
\text { and destination at google.com/maps }\end{array}$ \\
\hline
\end{tabular}

The data explored were analyzed in the third stage, initially separating the subsidized routes to isolated and non-isolated locations and applying the Mann-Whitney test. As independent samples, it was inferred that the null hypotheses of identical frequency distribution between flight distances, population of the locations served and GDP per capita for both situations are not acceptable. For this reason, the strategy of grouping the localities served from their geographical coordinates, population, distance, GDP per capita and isolation condition was adopted. For this purpose, the K-means algorithm of unsupervised clustering was applied. Nine clusters were then defined, bringing together the closest service profiles in terms of the chosen variables. From them, one can interpret the similarities and differences between services, locations and isolation and infer about the main purposes of the programs revealed by the data, allowing a descriptive, geographical and causal analysis of subsidized air services. Thus, mostly humanitarian and essential services can be distinguished from situations where the motivations are more linked to economic aspects, expansion of the regional network, and integration with the national network.

Additionally, a Principal Component Analysis (PCA) approach was used, to extract the most informative component amongst the six collected variable and thus validating the groupings extracted from the data. As considered by Tommy et al. (2020), the PCA method has been preferred in this type of study due to the absence of any decision related to group structure.

Based on this methodology, we seek to identify the geographical peculiarities of the routes and locations served, and if they allow distinguishing the essentiality of the subsidized air connection as a crucial line for the connectivity of certain locations when linked to the conditions of isolation. 


\section{Data and Materials}

\subsection{Geographic Characterization of the Locations Served}

The joined results allow a geographically defined visualization for the proper limits of the continents for a better understanding. The countries with public policies of subsidies to air transportation are located in Asia, Europe, Oceania, and the Americas, without any records of representatives of the African continent.

In a systematic approach by continent, it was possible to perceive the reasons and justifications for the policies and criteria adopted by the countries to subsidize air transport to unattended locations.

\subsection{Subsidized Regional Airlines in North America}

In North America, the United States stands out with initiatives established decades ago with the subsidy on regional transportation offered through the Essential Air Service (EAS), implemented to ensure that smaller cities would maintain air services, after the deregulation of the airline sector marked by the publication of the Airline Deregulation Act (ADA) of 1978 (Fig. 1). In summary, federal subsidies have been competitively allocated to commercial carriers to serve eligible communities without an existing air service (Merkert and Williams, 2013).

In Alaska and Canada, where temperatures well below zero degree Celsius severely restrict surface transport, even though winter roads allow vehicles to pass (Hall and Saarinen, 2010). The conditions for traveling on small boats and snowmobiles are common throughout the year, involving the use of extensive networks of trails on land, sea or ice and often involve travel of hundreds of kilometers and extended periods of hours or days to remote regions (Ford et al, 2019). In this scenario, air transport appears as a faster and safer option, given the most urgent needs of the population served.

Metrass-Mendes, de Neufville, and Costa (2011) analyzed the impact of Canadian air transport policy on accessibility to remote and Arctic communities, above latitude $55^{\circ}$ and where land access is practically nonexistent, and which seem to be unable to sustain and operate its infrastructure without receiving local or federal contributions. Thus, and because of climate, great distances and environmental concerns, Canada's remote regions are highly dependent on aviation for the transportation of passengers and cargo throughout the year.

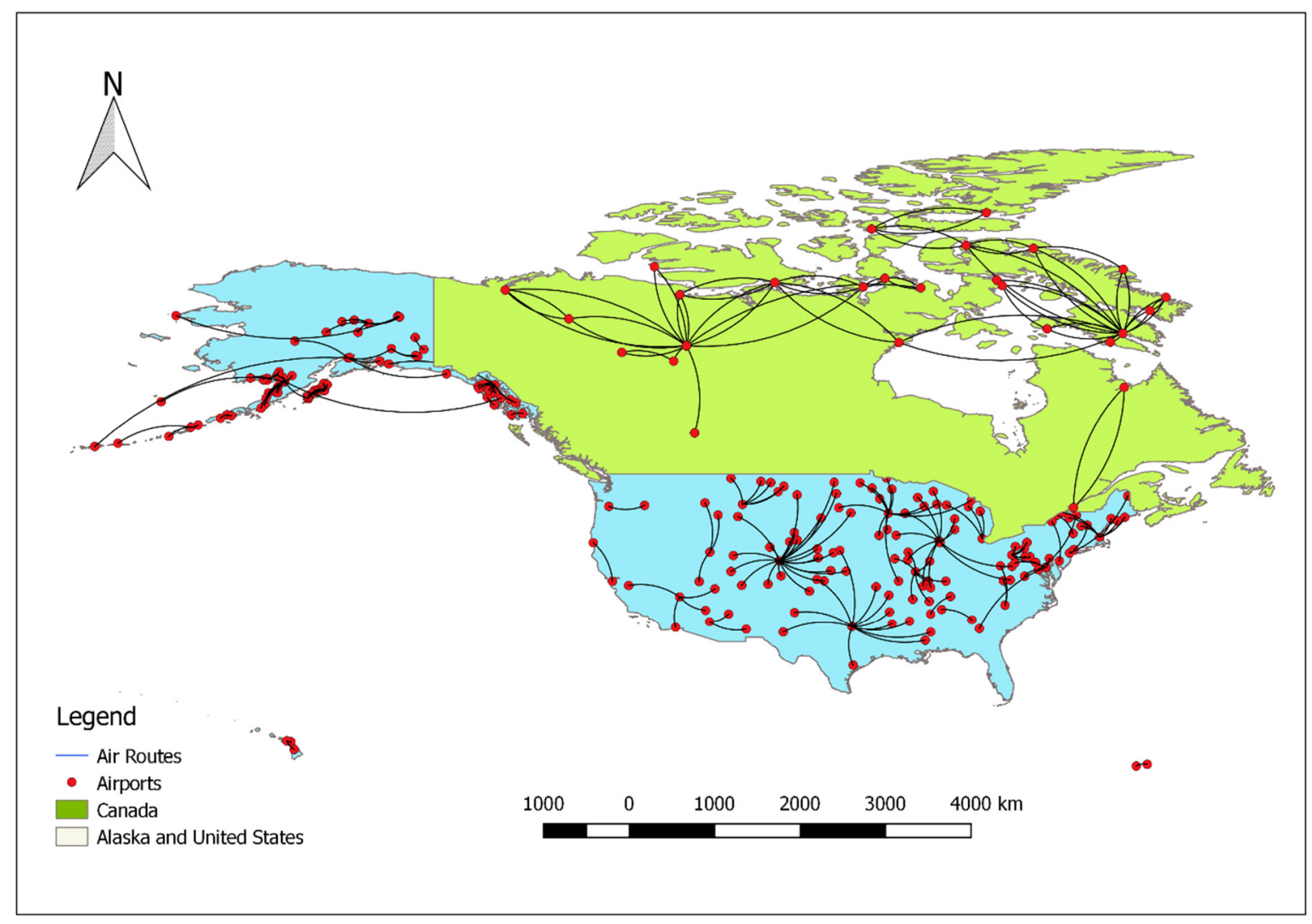

Figure 1. Subsidized routes in North America 


\subsection{Subsidized regional airlines in South America}

In the extreme south of the Americas, the Chilean Secretariat for Regional Development defined the regions of Magalhães and Tierra del Fuego as geographically isolated, with low accessibility levels for its sparse and dispersed population, and with low coverage of public services, which causes a situation of inequality in relation to the rest of the country. In 2018, 17 routes with subsidized passenger fares in the country were identified (Pérez, 2018).

In Brazil, action plans are generally made up of a financial contribution from the federal government to airport infrastructures, with due contribution, of a lesser value, from state governments, in addition to technically making the investment feasible with the bidding and inspection of the work (Brazil, 2016).

However, it is the isolated communities in the interior of the Amazon rain forest that make up the broadest geographical scenario for serving air routes subsidized by almost all countries with populations located in these regions, as shown in Figure 2. In general, the locations served are only accessible by river, after several hours or days of travel that are not offered regularly. In Ecuador, air transport is the only means of access to isolated communities in the Amazon region, as they do not have road routes and river transportation has several technical limitations, such as periods of the year when the river flow decreases and does not allow for safe navigation, or lack of infrastructure for mooring boats and embarkation or disembarkation of passengers (Ecuador, 2016). In Colombia, the social air services provided by the state company SATENA play an important role in connecting regions with geographic difficulties of access or social development, with costs covered by the national government (Colombia, 2019). As French overseas territory, the French Guiana uses the European PSO to subsidize routes between Cayena and communities located in the forest. In Guyana, Suriname and Venezuela, data on the topic were not found.

In Bolivia, subsidized air routes are operated by a state-owned airline. Military in nature, the TAMep Military Air Transport by Public Company - connects the main Bolivian cities to remote located communities (Bolivia, 2018).

Peru applies a program for promoting national aviation air operators to provide air services with regular frequency to isolated regions or with difficulties in land access routes and where there is no approved offer of regular air transport service (Peru, 2019). 


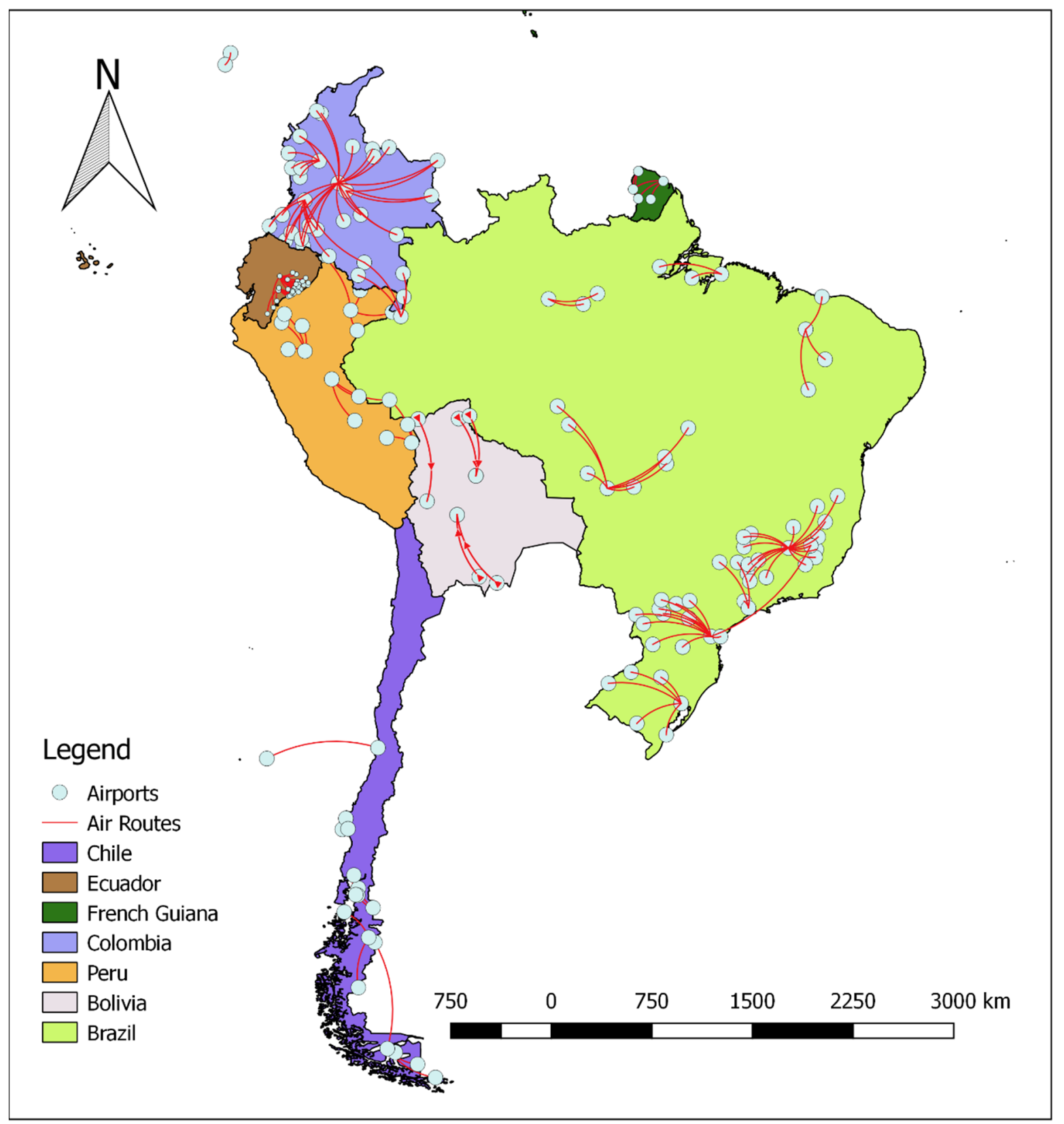

Figure 2. Subsidized routes in South America

\subsection{Subsidized Regional Airlines in Europe}

In Europe, regional airports, based on cost-benefit analyzes, should be able to compete for the financing of funds, in response to invitations from member states to submit proposals indicating the routes and compensation requested. The importance of making the outermost regions more competitive (islands for example) and promoting their integration with other regions, to overcome the economic gap that separates them from the rest of Europe, guides the countries of the continent to resort to the PSO subsidy (Portugal, 2008).

The Azores and the Canaries archipelagos deserve more considerable prominence, belonging to Portugal and Spain, respectively. Distant from the continental coast of the countries, the islands are users of the PSO subsidies to provide connectivity between them, because although they are not at substantial distances from each other, they do not have a fast mode of transport between them, with compatible travel time with what the air mode offers.

Since 1997, routes under the PSO regime have been established by the Norwegian government in the form of public tenders to guarantee air services to populations living in peripheral regions, which in a competitive market 
would rarely be served, through payments to private companies to provide transportation services in remote regions with low demand markets for air transport. Particularly, the north routes, under extremely reduced temperatures and rigorous winters with strong snowfall, which makes it difficult or delays surface transport, air service is desired by the population, but the expectation for great growth rates of air traffic in these sparsely populated areas seems unreal to stabilize the costs considering the level that the average fare demand for the due profit (Bubalo, 2012). Similar conditions are observed in neighboring countries such as Finland and Sweden, however with fewer routes and with characteristics of point to point displacement.

In Mediterranean countries, and in Ireland and Scotland, subsidized routes are concentrated on connections between islands close to the coast and larger cities located on the continental shelf, as shown in Figure 3.

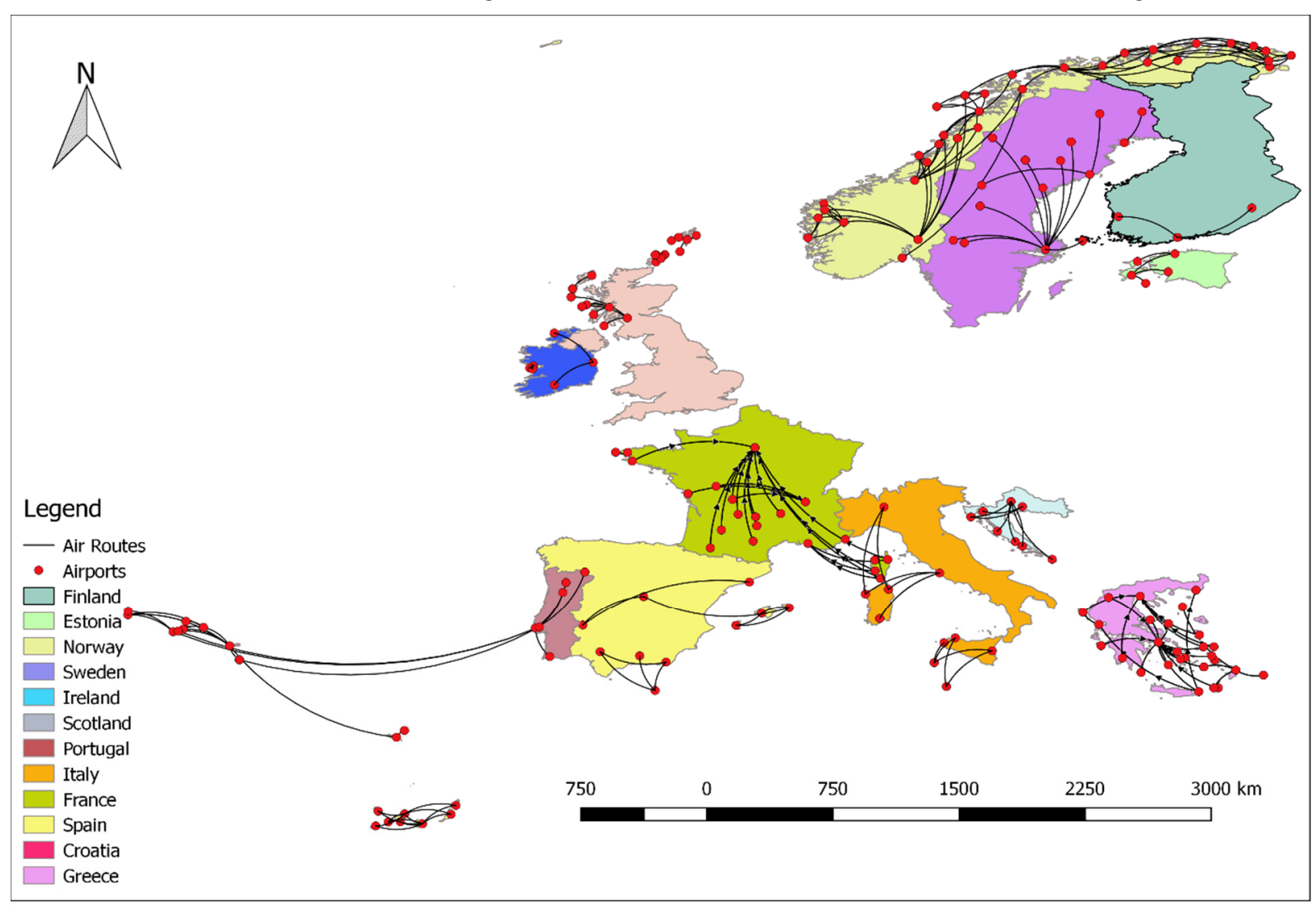

Figure 3. Subsidized routes in Europe

\subsection{Subsidized Regional Airlines in Continental Asia and Japan}

Subsidized routes are more concentrated in the Russian Federation (Figure 4), where connectivity plays an important role in supporting the life of the inhabitants, through transport and communications (Краев, Строев and Тихонов, 2018). Although the Russian program foresaw the creation of state-owned companies for the development of airports in those regions, the objective of the plan also aimed at increasing the air mobility of people and facilitating commercial activity between locations, without the historical need for connection in Moscow (Russia , 2012).

According to Gassanova and Madikenova (2017), there are seven regional airports in Kazakhstan carry less than 100,000 passengers annually, which makes them eligible to receive public funds at least to meet operating costs. In China, the national plan for the modernization of existing infrastructure and the construction of another 136 new airports between 2015 and 2025, accompanied by new routes and the inclusion of new cities in the air network, foresees the application of state subsidies (Dong and Ryerson, 2019).

In the vast Indian territory, the government implemented the Regional Air Connectivity Scheme (RCS), focusing on air connectivity where it was not present and motivating airlines to start flights to remote locations, with airports with low or no service (Chandrashekar Iyer, K. and Thomas, N., 2020).

In Japan, air routes to remote islands experience extremely severe commercial conditions because they serve areas where depopulation and aging are greater than the rest of the country. Thus, to ensure consistent air transport to 
these remote islands, air carriers receive incentives from the government through aircraft maintenance concessions, operating cost concessions, reduced landing fees, reduced taxes, and public fees (Japan, 2018).

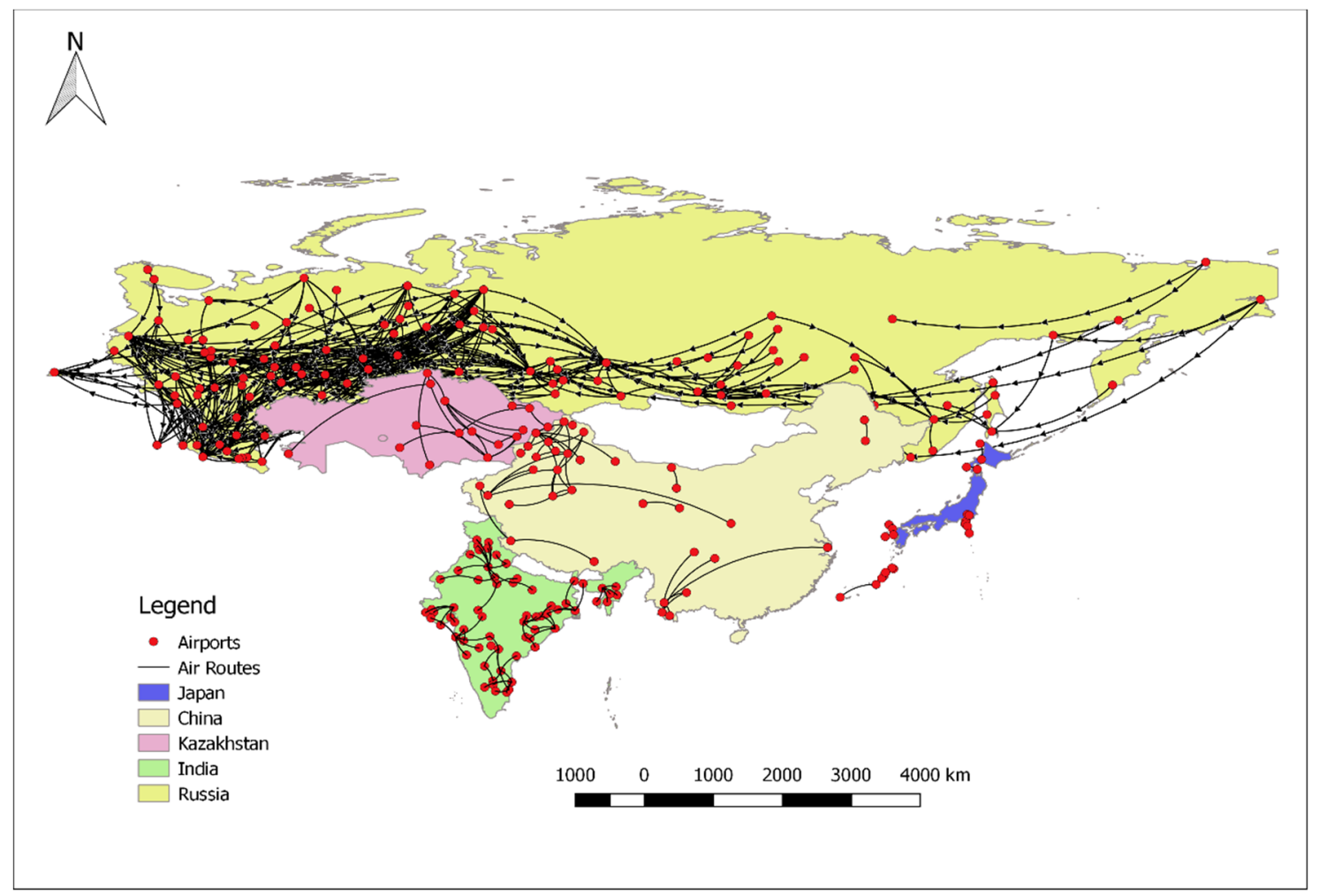

Figure 4. Subsidized routes in Asia

\subsection{Subsidized Regional Airlines in Southeast Asia}

The Pioneer Air Transport Program (PATP) funded by the Indonesian government, which aims to promote connectivity in the country's most remote communities, has been operating since 2017 as part of the current government's focus on addressing logistical issues in remote and underdeveloped areas, mainly in the Papua and Kalimantan regions (The Jakarta Post, 2018), as Figure 5 highlights. One of the most considerable challenges for the development of Papua, the most principal beneficiary of government subsidies, is the limited transport infrastructure, essential for the connectivity of its dispersed and isolated population that lives in the center of the island, on the slopes of steep mountains covered with dense vegetation (Ronting, Adisasmita and Hustim, 2018).

In neighboring Malaysia, the RAS (Rural Air Services) program is managed by the Federal Government and airlines operating the RAS routes may be eligible for subsidies. They are air services performed in the interior of the east of the country, where air transport represents an essential means of transport to connect people from different areas. Although the distances are short, the conditions of many roads make terrestrial displacement impracticable and the fluvial transport is the second better choice where it has navigable rivers. However, in most parts, air travel represents the only realistic choice and a valuable means of transport for rural residents who live in that region of the country, with rugged terrain covered by dense jungle (MAVCOM, 2020). 


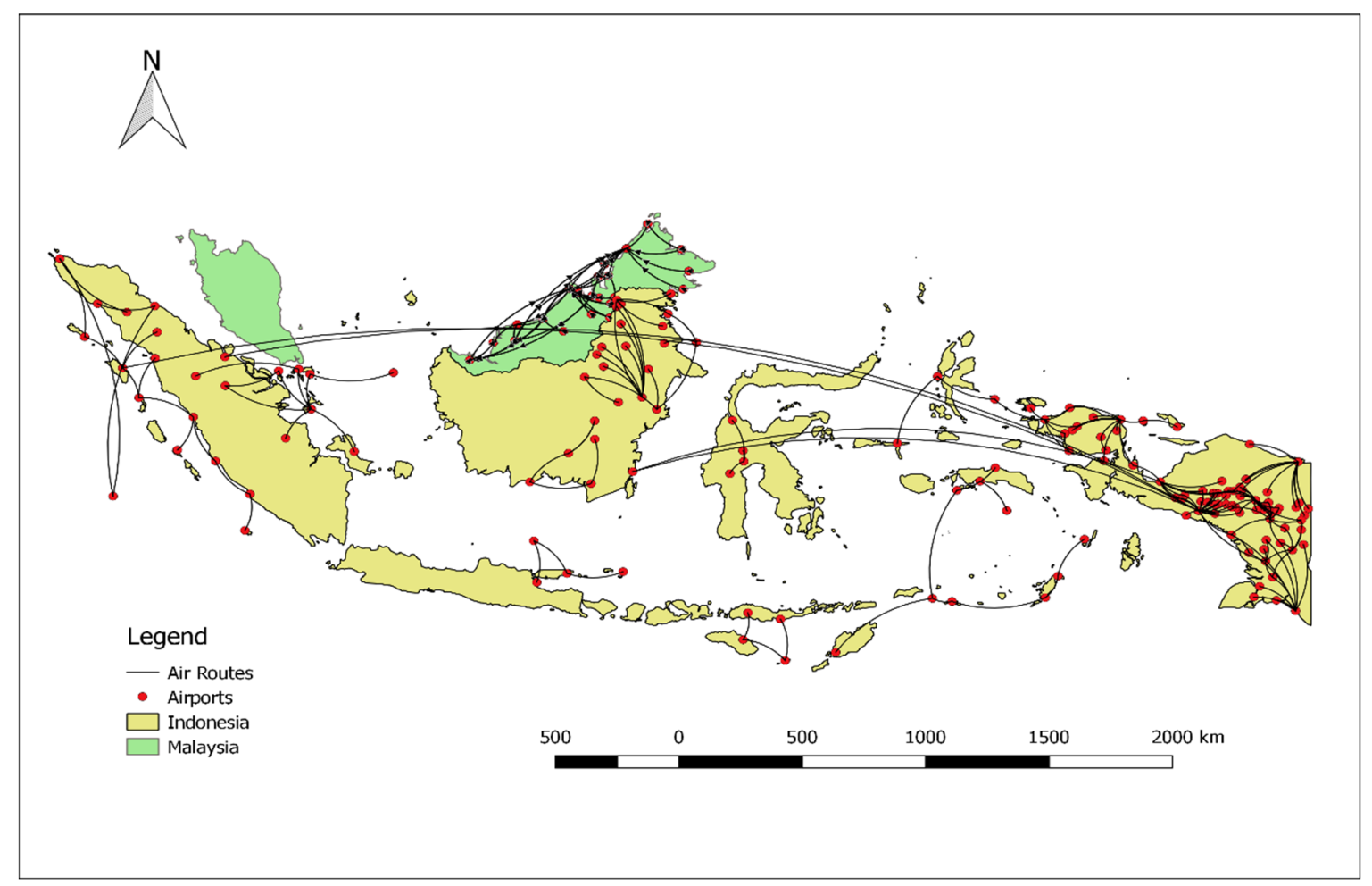

Figure 5. Subsidized routes in Asia Southeast

\subsection{Subsidized Regional Airlines in Australia}

In Australia, the Remote Air Services Subsidy Scheme (RASS) is part of the Regional Aviation Access Program (RAAP). RASS subsidizes a regular weekly air transport service for the transportation of passengers and goods, such as educational materials, medicines, fresh food and other urgent supplies for communities in remote and isolated areas of Australia, in 266 communities in the north of the country, among 86 of which are indigenous communities (Australia, 2020). Merkert (2017) says that these services are essential not only for economic sustainability, but also for the survival of Australia's regional communities. Therefore, in many jurisdictions these services are also called lifeline services. 


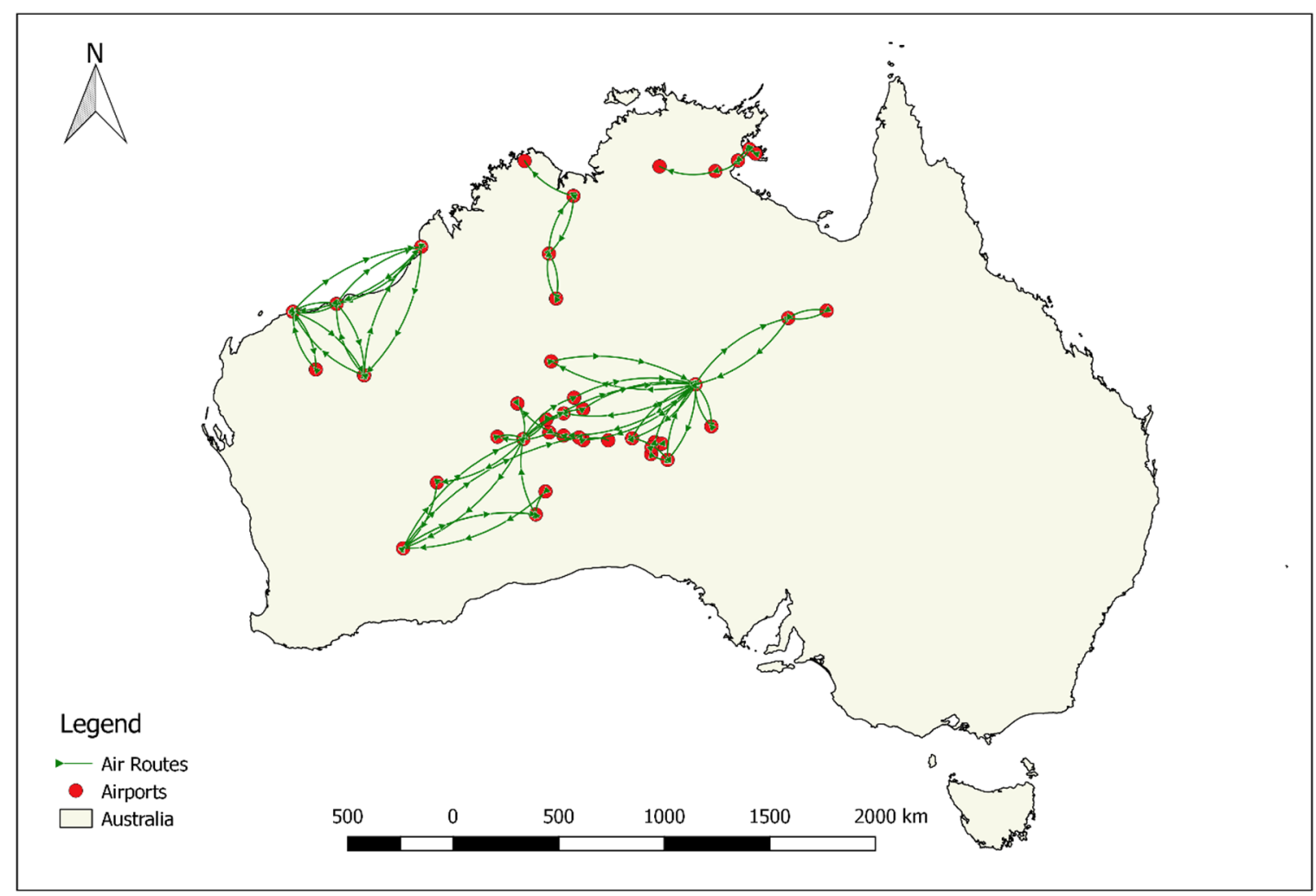

Figure 6. Subsidized routes in Oceania

\section{The Results and Discussion}

In a first analysis of the gathered data, it is noticeable that only $35.24 \%$ of the studied lines serve geographically isolated locations for reasons of insularity, severe climate and/or tropical forests. The median of flight distances from non-isolated locations is $578 \mathrm{~km}$, while for isolated communities it is $185 \mathrm{~km}$, which demonstrates the distance between the origin and destination of subsidized flights is considerably smaller for isolated communities, which was already expected. Also, the medians of the populations served are strongly differentiated between the isolated locations of about 3,800 people and the non-isolated towns of about 80,000 people. As for medians of GDP per capita, isolated areas have a median of US $\$ 13,350$, while nonisolated communities demonstrate a value of US $\$ 10,200$.

\subsection{Classification of Subsidized Routes in Clusters}

The classification by cluster presented in Table 2 allows for a geographical observation of the conditions and characteristics peculiar to each grouping, although initially constituted by locations in different countries, but similar in terms of the level of dependence on subsidies to air routes. 
Table 2. Classification of locations served by subsidized routes in clusters

\begin{tabular}{|c|c|c|c|c|c|c|c|c|}
\hline Cluster & Routes & $\begin{array}{l}\text { Locations } \\
\text { served }\end{array}$ & $\begin{array}{l}\text { \% of } \\
\text { Total }\end{array}$ & $\begin{array}{c}\text { Predominant } \\
\text { typical situation }\end{array}$ & $\begin{array}{c}\text { Average } \\
\text { distance } \\
(\mathbf{k m}) \\
\text { (Min- } \\
\text { Max) }\end{array}$ & $\begin{array}{l}\text { Average } \\
\text { population } \\
\text { (Min-Max) }\end{array}$ & $\begin{array}{l}\text { Average } \\
\text { GDP per } \\
\text { capita } \\
\text { (U\$) } \\
\text { (Min- } \\
\text { Max) }\end{array}$ & Countries \\
\hline 1 & 271 & 205 & 19,9 & $\begin{array}{l}\text { Small towns isolated } \\
\text { by climate, } \\
\text { insularity, or } \\
\text { equatorial forests in } \\
\text { the western } \\
\text { hemisphere. }\end{array}$ & $\begin{array}{c}332 \\
(23-1919)\end{array}$ & $\begin{array}{c}1.500 \\
(12- \\
920,232)\end{array}$ & $\begin{array}{c}24.214 \\
(2,351- \\
105,214)\end{array}$ & $\begin{array}{c}\text { United States } \\
\text { (Alaska), Greece, } \\
\text { Norway, France, } \\
\text { Scotland, Portugal, } \\
\text { Spain, Italy, Peru, } \\
\text { Ecuador, Colombia, } \\
\text { Chile, Guyana, } \\
\text { Canada and Brazil. }\end{array}$ \\
\hline 2 & 5 & 5 & 0,4 & $\begin{array}{c}\text { Small oil } \\
\text { exploration } \\
\text { locations isolated by } \\
\text { the weather. }\end{array}$ & $\begin{array}{c}174 \\
(20-236)\end{array}$ & $\begin{array}{c}90 \\
(94-2,339)\end{array}$ & $\begin{array}{c}130,900 \\
(148,621- \\
247,465)\end{array}$ & Alaska (USA). \\
\hline 3 & 138 & 134 & 10,1 & $\begin{array}{l}\text { Small and medium- } \\
\text { sized, middle- } \\
\text { income, non-isolated } \\
\text { cities }\end{array}$ & $\begin{array}{l}432 \\
(82- \\
3066)\end{array}$ & $\begin{array}{c}16.500 \\
(33- \\
28,456)\end{array}$ & $\begin{array}{c}55.500 \\
(699- \\
247.465)\end{array}$ & $\begin{array}{c}\text { Alaska, United States, } \\
\text { Canada and } \\
\text { Colombia. }\end{array}$ \\
\hline 4 & 14 & 9 & 1,0 & $\begin{array}{l}\text { Large, extremely } \\
\text { poor towns in } \\
\text { remote regions, but } \\
\text { not isolated by land. }\end{array}$ & $\begin{array}{l}390 \\
(171- \\
2865)\end{array}$ & $\begin{array}{c}2.430 .000 \\
(1.585 .704- \\
3.876 .001)\end{array}$ & $\begin{array}{c}2.800 \\
(972- \\
18,588)\end{array}$ & $\begin{array}{l}\text { India, China and } \\
\text { Kazakhstan. }\end{array}$ \\
\hline 5 & 178 & 129 & 13,0 & $\begin{array}{c}\text { Poor small towns } \\
\text { isolated by insularity } \\
\text { or by tropical forests } \\
\text { at small and medium } \\
\text { distances. }\end{array}$ & $\begin{array}{c}150 \\
(33- \\
1074)\end{array}$ & $\begin{array}{c}5.500 \\
(71- \\
223.446)\end{array}$ & $\begin{array}{l}4.380 \\
(1.677- \\
17.098)\end{array}$ & $\begin{array}{l}\text { Indonesia, Malaysia } \\
\text { and Australia. }\end{array}$ \\
\hline 6 & 138 & 55 & 10,1 & $\begin{array}{l}\text { Non-isolated cities } \\
\text { located in remote } \\
\text { parts of the territory } \\
\text { with low to middle } \\
\text { income. }\end{array}$ & $\begin{array}{c}2.200 \\
(1.092- \\
4.629)\end{array}$ & $\begin{array}{c}252.000 \\
(2,119- \\
1,259,013)\end{array}$ & $\begin{array}{c}11.150 \\
(3,230- \\
110,330)\end{array}$ & Russia \\
\hline 7 & 27 & 20 & 1,9 & $\begin{array}{c}\text { Asian cities isolated } \\
\text { at medium distances } \\
\text { by insularity or by } \\
\text { climate, of middle } \\
\text { income. }\end{array}$ & $\begin{array}{c}575 \\
(68- \\
4,993)\end{array}$ & $\begin{array}{c}13.000 \\
(1,684- \\
263,906)\end{array}$ & $\begin{array}{r}33.200 \\
(6,000- \\
90,640)\end{array}$ & Russia and Japan \\
\hline 8 & 212 & 162 & 15,6 & $\begin{array}{l}\text { Non-isolated small } \\
\text { and medium sized } \\
\text { towns at medium } \\
\text { distances, with low } \\
\text { to middle income. }\end{array}$ & $\begin{array}{l}375 \\
(151- \\
1,430)\end{array}$ & $\begin{array}{c}38.400 \\
(140- \\
951.588)\end{array}$ & $\begin{array}{c}10.800 \\
(2,039- \\
76,780)\end{array}$ & $\begin{array}{c}\text { Peru, Colombia, } \\
\text { Bolivia, Chile, } \\
\text { Indonesia, Malaysia, } \\
\text { India, Australia and } \\
\text { Brazil. }\end{array}$ \\
\hline 9 & 382 & 163 & 28,0 & $\begin{array}{l}\text { Non-isolated small } \\
\text { and medium sized } \\
\text { towns in the } \\
\text { northern hemisphere } \\
\text { in Europe and Asia. }\end{array}$ & $\begin{array}{c}614 \\
(38- \\
1,765)\end{array}$ & $\begin{array}{c}135.000 \\
(169- \\
1.259 .013)\end{array}$ & $\begin{array}{c}8.000 \\
(1,790- \\
42,540)\end{array}$ & $\begin{array}{l}\text { Finland, Norway, } \\
\text { Greece, Sweden, } \\
\text { France, Estonia, } \\
\text { Portugal, Spain, } \\
\text { Croatia, Ireland, } \\
\text { Kazakhstan, Russia, } \\
\text { India and China. }\end{array}$ \\
\hline
\end{tabular}

\subsection{Analysis using Principal Component Analysis (PCA)}

With the results of the PCA, it appears that the first three components explain about $72 \%$ of association, however the first two components together reveal almost $60 \%$, according to Table 3 . Thus, it was decided to consider the analysis in the first two axes (PC1 and PC2). In the analysis of the loads of components 1 and 2, we have that, the variables with greater representativeness, are in PC1: latitude, distance between cities and inaccessibility by land, in PC2 we have longitude and GDP, per Table 3. 
Table 3. Eigenvalues and eigenvectors analysis - PCA

\begin{tabular}{ccccccrr}
\hline \multicolumn{3}{c}{ Analysis of Eigenvalues of the Matrix of Covariance } & \multicolumn{4}{c}{ Eigenvectors (component loads) } \\
Eigenvalue & Ratio & & Accumulated & Variables & PC1 & PC2 \\
\hline & 1,75 & 0,31 & 0,31 & Latitude & $-0,57$ & 0,26 \\
2 & 1,57 & 0,28 & 0,58 & Longitude & 0,05 & $-0,60$ \\
3 & 0,78 & 0,14 & 0,72 & Distance in km & $-0,52$ & $-0,17$ \\
4 & 0,67 & 0,12 & 0,84 & Population & $-0,30$ & $-0,39$ \\
5 & 0,50 & 0,09 & 0,93 & GDP & $-0,22$ & 0,59 \\
6 & 0,42 & 0,07 & 1,00 & No access by land & 0,51 & 0,19 \\
\hline
\end{tabular}

Thus, the PCA brings a result that corroborates with the fact that geographic variables such as latitude, longitude and lack of access by land are important for subsidized routes and that among all variables the one that is less important is the population of the communities served. Furthermore, when evaluating the two main components considering routes with and without access by land, it is noticed that there is a tendency of grouping, which demonstrates that this variable is important to represent the phenomenon, as shown in Figure 7.

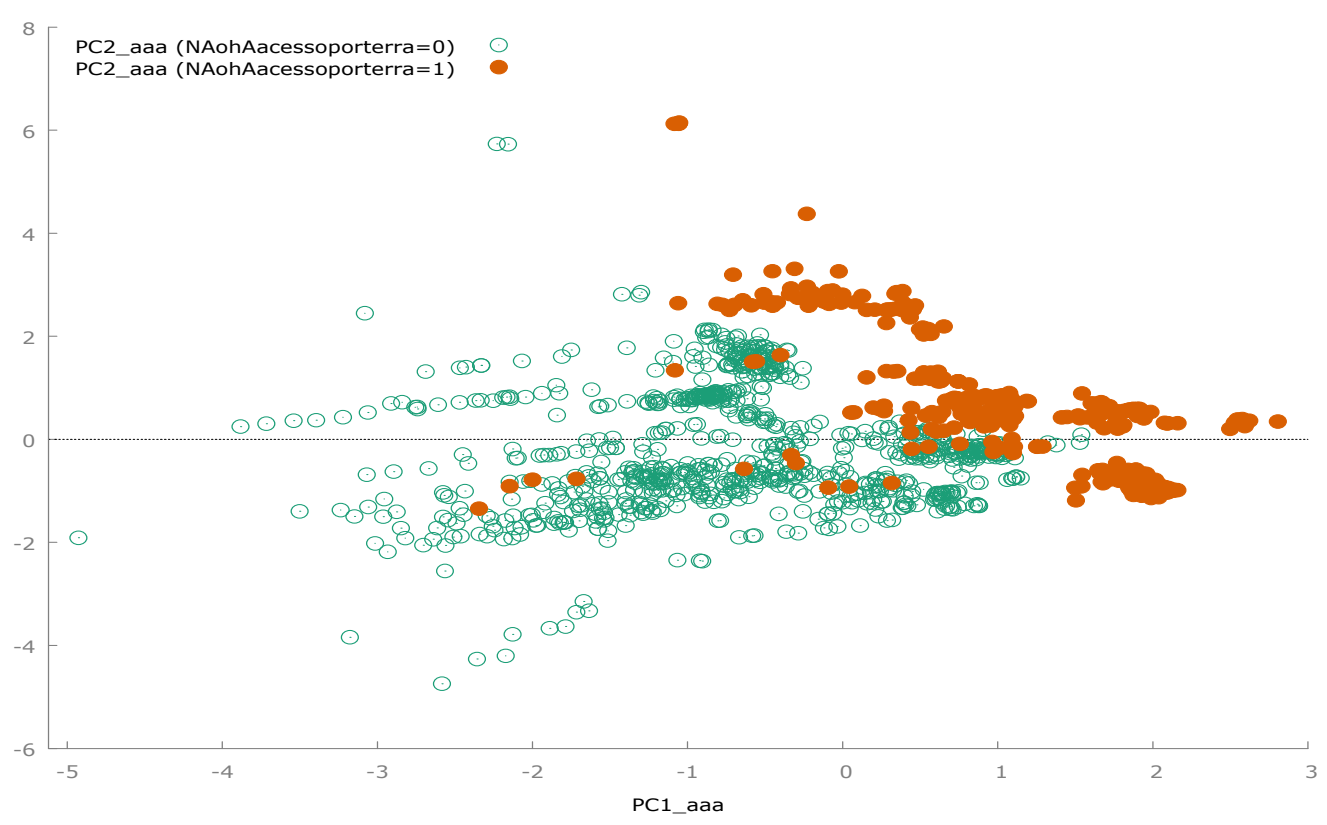

Figure 7. Grouping of routes into two groups: with and without land access

\subsection{Accessibility to Remote Locations without Land Access}

A worldwide analysis based on an expressive number of subsidized routes allowed to identify different characteristics of the subsidy programs applied in different countries of the world. The 1,365 routes observed in fact serve 882 locations, of which 393 (57\%) are located in the eight vastest countries in territorial extension. Only 57 of these locations do not have a reasonable alternative to substitute displacement by air. There is, therefore, a predominance of public policies focused on reducing travel time between towns that in general are at substantial distances and on improving the connectivity of each country's regular air transport market.

When considering the classification of the routes and communities served based on the formation of clusters, it is possible to observe that some locations express a very different relationship or dependence on air transport: the 514 locations that make up clusters 3, 6, 8 and 9 are not isolated by land, which makes them not depend on air transport as an exclusive mode of transport, while the other 368 locations, about $42 \%$, which form clusters 1, 2, 4, 5 and 7, are isolated by land, and have a greater dependence on air transport as a means of accessibility, having peculiarities in relation to their geographical condition, which can be grouped according to the criteria below: 
a) Island sites, located in various countries, usually close to the continental coast of the respective country, with road access combined with crossing by ferry or exclusively via ferry, requiring a high travel time for a connection of a few kilometers, due to the modal transfer of transport.

b) Locations located in the region defined by the Arctic Circle, above latitude $60^{\circ}$, subjected to extremely low temperatures during some months of the year, with difficulties or unviability for land access. They are located predominantly in the American state of Alaska, Canadian territories of Nunavut and Northwest, Scandinavian countries and northern Russia. In the southern portion, it includes locations in the southern tip of the Chilean territory of Magalhães.

c) Locations inserted in areas covered by dense vegetation, with precarious road access and / or uncertain waterway and without structure. They are represented by isolated communities in the Amazon and in Asia, especially on the islands of Borneo and Papua, where the mountainous relief aggravates the condition of isolation.

The communities submitted to severe winter conditions total 81 isolated locations, of which 75 (93\%) are extremely dependent on air transport, and 59 are served by a single subsidized route. They are situated in Alaska in the United States, or in Nunavut and the Northwest Territories in Canada, the Scandinavian countries, with emphasis on Norway, with 79 routes that serve 32 cities in the far north with connections to their main cities in the region, Bodo, Trondheim, and Tromso; and among eache other in Russia, in addition to villages in the south of Chile, with 17 routes, which connect remote communities in the Magellan region to the cities of Puerto Montt and Punta Arenas, locations where land displacement conditions are unviable for much of the year. Of the 34 routes connecting communities in northern Canada to cities in the main air transport network such as Iqaluit and Yellowstone, 30 do not have a substitute alternative for displacement, attributing to regional routes a fundamental role in the connectivity of the inhabitants of those regions. In Alaska, there are 63 routes, 50 of which have no alternatives even during the summer months in the northern hemisphere.

But it is in the conditions of places in the middle of dense forests that a more considerable degree of dependence is observed: of the 151 locations in these conditions, 150 are dependent on air transport as the only viable means of connectivity. It is also in Indonesia the highlight for air connectivity through the Pioneer Air Transport Program (PATP), with subsidized routes to 91 locations inserted in the middle of the forests of Papua and Borneo - the latter also served by Malaysian routes -, mountain regions covered by vast vegetation and whose road access is precarious or non-existent. The other routes serve locations located in the countries that make up the Amazon, like Bolivia, Peru, Ecuador, Colombia, Brazil and the French overseas territory of Guyana.

The clusters found show that the geographic characteristics of the locations served by air routes benefiting from any type of subsidy differentiate the supposed objectives of the various public policies applied. If in part of the locations served, the objective suggests connecting towns accessible by land as an alternative to reduce travel costs and promote economic development, based on the dependence on air transport demand in relation to the size and income of the population, as clusters $3,6,8$, and 9 gather, a significant portion of the locations served that are gathered in clusters $1,2,4,5$, and 7 aggregate isolated communities, without viable and fast land access, generally of modest income and smaller, which depend more heavily on aerial connection to access larger centers for the most basic needs, health and subsistence, as well as to access the air network and, therefore, connect with other locations.

\section{Conclusions}

When analyzing the universe of routes served by different countries in the world, it was observed that a high number of locations served depend on air transport as the only viable access to guarantee their connectivity with other centers to meet various basic services, personal needs such as traveling to visit family members, medical services, or even to meet business or tourism needs. The literature recognizes such routes as lifelines, due to the humanitarian importance they have for isolated communities without land access. Recognizing that these locations have geographical characteristics that make them dependent on air transport is essential to conduct new policies or adjust existing ones to apply subsidies to humanitarian routes, dissociated from the aspects of economic development that generally lead to research and study of subsidizing aerial routes.

This study allows the identification of remote locations served and highlights isolated communities through a classification that considers three conditions of geographic isolation: islands, proximity to polar extremes and location in the middle of equatorial forests. Regardless how many initiatives are identified in different countries, with different geographical and economic conditions, there is a convergence towards the objective of integrating communities into the national air transport network. However, for isolated, poor and low-population locations, the subsidy for air transport is justified as a vital means for the access of these populations to basic social and humanitarian services, which goes beyond a mere economic development objective. 
Thus, the study of subsidies to air transport to remote and isolated locations gains new horizons to be explored within the field of social sciences and not solely economic ones, in which models of programs implemented by different countries can be compared and evaluated, regarding the efficiency of application of public funds increasingly scarce and questioned. Other valuable research would be the evaluation of subsidized air routes by means of social benefits and improvements on the quality of life in the most deprived and dependent locations

\section{References}

Australian Government, Department of Infrastructure, Transporte, Regional Development and Comunication. Remote Air Services Subsidy Scheme - The Mail Plane. (2017). Retrieved June 24, 2020, from http://www.infrastructure.gov.au/aviation/regional

Bråthen, S., \& Eriksen, K. S. (2016). Regional aviation and the PSO system e Level of Service and social efficiency. Journal of Air Transport Management, $\quad X X X, \quad 1-9$. https://dx.doi.org/10.1016/j.jairtraman.2016.10.002 0969-6997

Bråthen, S., \& Halpern, N. (2012). Air transport service provision and management strategies to improve the economic benefits for remote regions. Research in Transportation Business \& Management, 4, 3-12. https://doi:10.1016/j.rtbm.2012.06.003

Bubalo, B. (2012). Social costs of public service obligation routes - calculating subsidies of regional flights in Norway. Netnomics, 13, 125-140. https://doi.org/10.1007/s11066-013-9074-8

Chandrashekar Iyer, K., \& e Thomas, N. (2020). A Critical Reviem on Regional Connectivity Scheme of India. Transportation Research Procedia 48, 47-59. World Conference on Transport Research - WCTR 2019, Mumbai, 26-30 May 2019. Retrieved from http://creativecommons.org/licenses/by-nc-nd/4.0/

Chen, Z. (2017). Impacts of high-speed rail on domestic air transportation in China. Journal of Transport Geography, 62, 184-196. http://dx.doi.org/10.1016/j.jtrangeo.2017.04.002

Cheung, T. K. Y., Wong, C. W. H., \& Zhang, A. M. (2019). The evolution of aviation network: Global airport connectivity index 2006-2016. Transportation Research Part E: Logistics and Transportation Review, 133, 1366-5545. https://doi.org/10.1016/j.tre.2019.101826

Cruz-Rodriguez, I. J., \& Rodriguez-Flores, J. F. (2019). Crecimiento económico y tráfico aéreo de pasajeros: un análisis para las entidades federativas en México. Revista de Alimentación Contemporánea y Desarrollo Regional Volumen 29, Número 53. Revista electrónica.

Dong, X., \& Ryerson, M. S. (2019). Increasing civil aviation capacity in China requires harmonizing the physical and human components of capacity: A review and investigation. Transportation Research Interdisciplinary Perspectives 1. https://doi.org/10.1016/j.trip.2019.100005

Estado Plurinacional de Bolivia. Gaceta Aeronautica. Transporte Aéreo Militar - Bolivia - ¿Para qué?. (2018). Retrieved June 30, 2020, from https://www.gacetaeronautica.com/gaceta/wp-101/?p=29601

Fageda, X., Suárez-Alemán, A., Serebrisky, T., \& Fioravanti, R. (2018). Air connectivity in remote regions: A comprehensive review of existing transport policies worldwide. Journal of Air Transport Management, 66, 65-75. https://dx.doi.org/10.1016/j.jairtraman.2017.10.008

Fengjun, J., Fahui, W., \& Yu, L. (2004). Geographic Patterns of Air Passenger Transport in China 1980-1998: Imprints of Economic Growth, Regional Inequality, and Network Development. The Professional Geographer, 56(4), 471-487.

Ford, J. D., Clark, D., Pearce, T., Berrang-Ford, L., Copland, L., Dawson, J., Nem, M., \& Harper, S. L. (2019). Changing access to ice, land and water in Artic communities. Nature Climate Change Research. https://doi.org/10.1038/s41558-019-0435-7

Fu, Q., \& Kim, A. M. (2016). Supply-and-demand models for exploring relationships between smaller airports and neighboring hub airports in the U.S. Journal of Air Transport Management, 52, 67-79. https://dx.doi.org/10.1016/j.jairtraman.2015.12.008

García, C. G. (1983). Región, Política y Transporte Aéreo. Tesis Doctoral. Departamento de Análisis Geográfico Regional e Geografia Física. Universidad Complutense de Madrid, España.

Gassanova, A. A., \& Madikenova, A. A. (2017). Modern State and Prospects for development of Kazakhstan Aviation Market. Suleyman Demirel University Bulletin, Almaty, Kazakhstan.

Gillen, D., \& Hazledine, T. (2015). The economics and geography of regional airline services in six countries. 
Journal of Transport Geography, 46, 129-136. https://dx.doi.org/10.1016/j.jtrangeo.2015.06.009

Gobierno del Ecuador. Secretaría Nacional de Planificación y Desarollo. Instituto para el Ecodesarollo Regional Amazónico - ECORAE. Plan Integral para la Amazonía. (2016).

Gobierno del Peru, Ministerio de Transportes y Comunicaciones (MTC). (2019). Noticias Legales - El Peruano. Resolución Ministerial No 173/2019.

Goetz, A., \& Budd, L. (2014). The Geographies of Air Transport. Ashgate Publishing Limited.

Grubesic, T. H., \& Wei, F. (2012). Evaluating the efficiency of the Essential Air Service program in the United States. Transportation Research Part A 46, 1562-1573. https://dx.doi.org/10.1016/j.tra.2012.08.004

Hall, M., \& Saarimen, J. (2010). Polar Tourism: Definitions and Dimenions. Scandinavian Journal of Hospitality and Tourism, 10(4), 448-467. https://dx.doi.org/10.1080/15022250.2010.521686

Humphreys, I., \& Francis, G. (2016). Policy issues and planning of UK regional airports. Transport Policy, $52,46-54$.

IATA. International Air Transport Association.74th Annual General Meeting. Annual Review 2018, Sidney, Australia.

Keeling, D. J. (2008). Transportation Geography - new regional mobilities. Progress in Human Geography, 32(2), 275-283. http://phg.sagepub.com/content/32/2/275

Laurino, A., Beria, P., Debernardi, A., \& Ferrara, E. (2017). Accessibility to Italian remote regions: Comparison among different transport alternatives. Transport Policy, xxx, 1-12. https://doi.org/10.1016/j.tranpol.2017.12.009

Lopes Júnior, W. M. (2011). Turismo, Transportes e Regionalização: Considerações Geográficas. RA'EGA 26, 170-193 CD), Departamento de Geografia - UFPR. Retrieved from www.geografia.ufpr.br/raega

Malaysian Aviation Comission MAVCOM. How Rural Air Services (RAS) Helps. Retrieved September 7, 2020, from https://www.mavcom.my/en/industry/public-service-obligations/how-rural-air-services-rashelps/

Masayoshi, N., \& Trevor, B. (2012). The development of budgets and their use for purposes of control in Japanese aviation, 1928-1945. Accounting, Auditing \& Accountability Journal, 25(3). https://doi.org.10.1108/09513571211209590

Merkert, R. (2018). Inquiry into the operation, regulation and funding of air route service delivery to rural, regional and remote communities. The operation, regulation and funding of air route service delivery to rural, regional and remote communities Submission 97. Institute of Transport and Logistics Studies. The University of Sydney Business School.

Merkert, R., \& Williams, G. (2013). Determinants of European PSO airline efficiency e Evidence from a semi-parametric approach. Journal of Air Transport Management, 29, 11-16. https://dx.doi.org/10.1016/j.jairtraman.2012.12.002

Metrass-Mendes, A., de Neufville, R., \& Costa, A. (2011). Air Accessibility in Northern Canada: Prospects and Lessons for Remoter Communities. ERSA conference proceedings. European Regional Science Association. Retrieved from https://www.researchgate.net/publication/241769030

Oliveira, A. V. M., \& Silva, L. H. S. (2008). Constituição do Marco Regulatório Para o Mercado Brasileiro de Aviação Regional. Instituto Tecnológico da Aeronáutica (ITA) / Instituto de Pesquisa Econômica e Aplicada (IPEA).

Pérez, V. de la M. (2018). Caracterización de Subsidios Aéreos em Chile. Tese de Mestrado. Univerdad de Chile, Santiago.

República Argentina, Ministerio de Transporte. Carta del Ministerio de Transporte - La Revolucion de los Aviones. (2019). Retrieved June 30, 2020, from http://www.casarosada.gov.ar/79-informacion

República de Colombia. Aeronautica Civil. Atencion al Ciudadano. Política de servicios aéreos sociales. (2019). Retrieved June 30, 2020, from http://www.aerocivil.gov.co/atencion

República de Portugal. Regulamento (CE) No 1008/2008 do Parlamento Europeu e do Conselho de 24 de setembro de 2008 realtivo a regras comuns de exploração dos serviços aéreos na Comunidade (reformulação). Jornal Oficial da União Europeia. (2008). Retrieved June 21, 2017, from https://www.anac.pt/SiteCollectionDocuments/Regulacao Economica 
República Federativa do Brasil, Secretaria de Aviação Civil (SAC). Aviação regional. (2016). Retrieved December 12, 2019, from https://www.infraestrutura.gov.br/aviacaoregional.html

Rodrigue, J. et al. (2006). The geography of transport systems. Abingdon, Oxon, England; New York: Routledge.

Rodrigue, J. P. (2016). Transport geography. International Encyclopedia of Geography: People, the Earth, Environment and Technology: People, the Earth, Environment and Technology, 1-9.

Ronting, Y., Adisasmita, S. A., Hamid, S., \& Hustim M. (2018). Optimization and Flight Schedules of Pioneer Routes in Papua Province. IOP Conf. Series: Earth and Environmental Science 140, 012081. https://doi.org.10.1088/1755-1315/140/1/012081

Roos, J. M., Sprei, F., \& Holmberg, U. (2020). Sociodemography, geography, and personality as determinants of car driving and use of public transportation. Behavioral Sciences, 10(6), 93.

Russian Federation Government, Oficial site. O primeiro-ministro Dmitry Medvedev realiza uma reunião em Novosibirsk sobre o tráfego regional de passageiros aéreos. Retrieved June 13, 2020, from http://archive.government.ru/eng/ docs/20033/

Ryerson, M. S., \& Woodburn, A. (2014). Build Airport Capacity or Manage Flight Demand? How regional planners can lead American aviation into a new frontier of demand management. Journal of the American Planning Association, 80, 138-152. Retrieved from http://www.tandfonline.com/action/showCitFormats?doi=10.1080/01944363.2014.961949

SAATM - The Single African Air Transport Management. An Agenda 2063 Flagship Project, 2017.

Santos, A. (2001). Natureza do Espaço - Técnica e Tempo, Razão e Emoção.

Shaw, J., \& Hesse, M. (2010). Transport, geography and the 'new' mobilities. Journal compilation Royal Geographical Society (with The Institute of British Geographers) Trans Inst Br Geogr NS 35 305-312.

Skipin, D. L., \& Gushchina, A. S. (2018). Techniques for efficiency assessment of subsidized air transportation as the basis for reasoned management decisions. Vestnik Permskogo universiteta. Seria Ekonomika $=$ Perm University Herald. Economy, 13(4), 638-653. https://doi.org.10.17072/1994-99602018-4-638-653

The Jakarta Post. Remote Area Flights yet to fullfill ICAO Standards. (2020). Retrieved July 20, 2020, from https://www.thejakartapost.com/news/2018/03/02/remote-area-flights-yet-to-fulfill-icao-standardsofficial.html

Turolla, F. A., Lima, M. F. F., \& Ohira, T. H. (2011). Políticas Públicas para a competitividade da aviação regional brasileira. Revisão de Literatura dos Transportes, 5(4), 188-231. Retrieved from https://www.researchgate.net/publication/50224263

Wallingre, N. (2010). Responsabilidad del transporte aéreo en la dinámica territorial para el Desarrollo del turismo argentine. El aporte pendiente. Revista Transporte y Territorio $\mathrm{N}^{\circ} 2$, Universidad de Buenos Aires. Retrieved from http://www.rtt.filo.uba.ar/RTT00206099.pdf

Wittman, M., Allroggen, F., \& Robert, M. (2016). Public service obligations for air transport in the United States and Europe: Connectivity effects and value for money. Transportation Research Part A, 94, 112-128. https://dx.doi.org/10.1016/j.tra.2016.08.029 0965-8564

Wu, H., Tsui, K. W. H., Ngo, T., \& Lin, Y-H. (2020). Impacts of aviation subsidies on regional wellbeing: Systematic review, meta-analysis and future research directions. Transport Policy, 99, 215-239. https://doi.org/10.1016/j.tranpol.2020.08.003

Young, C., \& Grobelna, A. (2018). Characteristics of remote and isolated health care facilities: an environmental scan. Ottawa: CADTH. (Environmental scan; no. 73).

Краев, В. М., Строев, В. В., \& Тихонов, А. И. (2018). Авиационные перевозки для обеспечения связанности территорий Российской Федерации. УПРАВЛЕНИЕ, 1(19), 62, 4-11. https://doi.org.10.26425/23093633-2018-1-4-11 


\section{Copyrights}

Copyright for this article is retained by the author(s), with first publication rights granted to the journal.

This is an open-access article distributed under the terms and conditions of the Creative Commons Attribution license (http://creativecommons.org/licenses/by/4.0/). 